\title{
Paideusis
}

\section{Doing Dewey Right: Pragmatic Perspectives for Politics and Education}

John M. Novak

Volume 10, Number 2, 1997

URI: https://id.erudit.org/iderudit/1073180ar

DOI: https://doi.org/10.7202/1073180ar

See table of contents

Publisher(s)

Canadian Philosophy of Education Society

ISSN

0838-4517 (print)

1916-0348 (digital)

Explore this journal

Cite this article

Novak, J. (1997). Doing Dewey Right: Pragmatic Perspectives for Politics and Education. Paideusis, 10(2), 13-24. https://doi.org/10.7202/1073180ar viewed online.

https://apropos.erudit.org/en/users/policy-on-use/ 


\title{
Doing Dewey Right: Pragmatic Perspectives for Politics and Education
}

\author{
John M. Novak, Brock University
}

Concerns about the vitality of ... political life, citizen apathy, growing disparities among citizens in wealth and power, and conflict among racial and ethnic groups make Dewey's conception of public life attractive. Communities in which all share in the creation and enjoyment of common goods, in which each person's flourishing is thought necessary for the full flourishing of the others and the individuality of each is respected, and in which conflicts are brought out in the open and resolved through public discourse surely are a worthy goal. (Robertson, 1992, p. 374)

Using a Deweyan perspective, this paper explores the development of worthy democratic goals and defensible ways to seek them. Doing Dewey right is to take seriously his approach, even in the most difficult situations.

From a Deweyan perspective, all events involve continuity and interaction (Dewey, 1938). That is, all events carry aspects of the past into the live encounters of the present, which in turn help shape the future. And so, the present is not an immaculate, encapsulated moment but a unique, live interaction bringing together what has happened with what might happen. This paper is certainly is no exception; it, too, possesses a history and a hope. It will examine the history of one recent Dewey-Russell debate with the hope of moving from diatribe to dialogue. The attempt will be made to do Dewey right (and, perhaps, do Russell more adequately) by recollecting what has gone before, reflecting on present possibilities, and reconstructing hopeful directions for democratic development. Thus, this paper will attempt to show the theory and practice of doing Deweyan democracy.

\section{Recollections}

Historically, this discussion is based on a continuation of the many and varied professional and personal exchanges between John Dewey and Bertrand Russell (Mayer, 1985). In spite of the salient similarities between the two-both were humanist philosophers, liberals, and educators (and have had biographies written about them by Alan Ryan [1988; 1995]), there are significant differences in how they connected philosophy, politics, and education. It has been my contention that Dewey's pragmatism runs deep, was never adequately dealt with by Russell, and that his criticism of Dewey often missed the mark. From my perspective, this mark-missing tradition was carried on by Michael Rockler in the last two debates we have had on "Dewey versus Russell."

This is our fourth Dewey-Russell event. In the first in 1991, Michael Rockler used Russell's and I used Dewey's humanistic perspectives to attack indoctrination in education. We often arrived at similar conclusions, sometimes for different reasons, but the event was a philosophically amicable affair. Tim Madigan, the Don King of philosophical match-making, provided an opportunity to "get it on" again in 1992, this time using a debate format in looking for points of disagreement on education. With Madigan participating by presenting a more balanced overview of each, Rockler and I found some key areas of disagreement. ${ }^{1}$ 
The substance and style of the 1992 debate can be summarized briefly by presenting Rockler's main charges $(C)$ against Dewey along with my responses (R):

1. (C) Dewey supported unqualified democracy in education. (R) Dewey's Lab School emphasized participatory virtues but teachers and students did not equally decide everything. This would not make the best use of a teacher's mature judgments.

2. (C) Dewey did not come to terms with the troublesome nature of induction. (R) Dewey did not begin with the infallibility of induction but instead looked at the self-correcting ways we solve actual problems in daily life and science.

3. (C) Dewey felt that truth was merely what the majority believed and, thus, gave in to a type of "herd instinct democracy." (R) Majority rule is not the essence of Dewey's democracy and it makes even worse epistemology. Dewey emphasized the ideal of the intelligent workings of a community of inquirers in developing warranted assertions.

4. (C) Dewey implicitly supported a "dead-level uniformity" through his emphasis on democracy in education. (R) The attempt in the Dewey School was to integrate individual differences authentically into desirable common ends. There is a creative individualism aimed for in doing this.

5. (C) Dewey believed in democracy as a result of the uncritical socialization he received in the American public schools. (R) Dewey's Lab School was a thoughtful deviation from his socializing Vermont schooling experiences and needs to be seen as an attempt to move democracy in a new and more social direction.

6. (C) Dewey naively applied science to all realms and was, thus, out-oftouch with the qualitative aspects of life. (R) Dewey, the author of Art as Experience (1934), saw science as an exemplar of a self-correcting method of inquiry. Works of art also use self-correcting methods in enabling us to attend to and extend the qualitative aspects of life.

7. (C) Dewey became a follower of Rousseau and, thus, did not focus heavily on the acquisition of knowledge. (R) Dewey offered a strong criticism of Rousseau in Democracy and Education (1916). The Deweyan curriculum aimed to connect the acquisition of knowledge with individual interests and social problems.

8. (C) Dewey had merely a negative theory of education. (R) Dewey's theory of education was an attempt to develop the positive virtues, practices, and structures necessary for individual development through democratic participation.

With the sparks still flying, Tim Madigan decided that a third meeting on Russell versus Dewey on religion, would further fan the flames of free inquiry. In that 1994 debate, I began by stating that Dewey's primary philosophical commitment was to a deepening of experiences which enabled people to live more connected and more meaningful lives. He differentiated "religion" from "religious." The former dealt with specific creeds, rituals, and supernatural beliefs which have a tendency to provide avenues of escape from human experiences. The latter, an adjective, applies to experiences in which we feel deep connections to worthwhile projects and life events. Dewey felt that deepconnected, savoured, growth experiences were vital to human existence. He thought that seeking to escape to realms outside of experience worked against making authentic connections in experience; he believed that experience could 
provide the means for its own growth. Interestingly, it could be said that Dewey sought to save the "religious" from "religion."

In his Russellian reaction to this Deweyan perspective, Rockler argued that because Dewey retained the the word "religious," he should be excluded from the roll of great secular humanists. According to Rockler (1995):

Russell embraced secular humanism at a very early age and never attempted to reconcile his position with the religious views of the masses. He rejected all propositions for which there could be no evidence (p. 37)

Later, in summarizing his position, Rockler stated that:

The difference between Russell and Dewey comes about in part because of their different backgrounds and intellectual capacities. Russell was able to defy the herd and give up any semblance of religion and religious activity. Dewey was not. (p. 38)

What could be read into these statements, without great effort, is that Dewey's perspective on religion is weak because he never escaped his early socializing experiences, he lacked the conviction to step outside the crowd, and he was probably not bright enough to really do so. For a Deweyan, these are fighting words. But also for a Deweyan, fighting can get in the way of intelligent inquiry. We can do better. We should do better. Democracy and education need better.

\section{Reflections}

Meeting \#1 (On Indoctrination): Interestingly, just as Russell and Dewey had sharp philosophical differences, "they found themselves on the same side of a moral issue on more than one occasion" (Sleeper, 1991, xx). So, too, Rockler's Russell and my Dewey shared a strong political and educational opposition to indoctrination. When push came to shove, Dewey's and Russell's political and educational sensibilities and actions converged. Certainly, there were differences, but a common anti-educational foe could bring them together. Thus, it would seem that some deep-seated commonalties could be tapped into to right perceived wrongs. However, in executing a common foe, it is important that a firing squad made up of Russellians and Deweyans organize themselves in a straight line rather than a circle.

Meeting \#2 (On Education): In a debate format, agreements were disregarded and disagreements exaggerated. Perhaps Rockler's perspective on Dewey would have been altered if he better attended to the following comments by Russell about Dewey:

Education, especially, has been in the forefront of his interests, and his influence on American education has been profound. I, in my lesser way, have tried to have an influence on education very similar to his. Perhaps he, like me, has not always been satisfied with the practice of those who professed to follow his teaching, but any new doctrine, in practice, is bound to be subject to some extravagance and excess. (1945, p. 819)

Russell's stated respect for Dewey's approach to education and his dissatisfaction with some who professed to follow his own teaching should throw some caution to those who attempt to use Russell to extravagantly and excessively attack Dewey.

However, in spite of what I felt were eight misfirings on the part of 10(2), (Winter) 1997 
Rockler, I think it is important to recognize that there are difficulties for those interested in doing Dewey's democratic education. Democracy is not as easy as Dewey sometimes made it seem. Working for democratic education and forming democratic publics need some middle-range political strategies that Dewey neglected (Westbrook, 1991). In defending themselves from detractors, Deweyan educators tend to gloss over these difficulties.

Deweyan democracy is not easy. Democratic schools need teachers knowledgeable in, and committed to, the sagacious use of democratic practices. Democratic teachers need the support of democratic teacher educators who "not only have to 'know their stuff,' they also have to model and make available for inspection their approaches to democratic teaching" (Novak, 1994, pp. 1-2). If a liberally-oriented teacher educator such as Michael Rockler could so misperceive Dewey's democratic education, there is an important need to clarify the key concepts of Dewey's approach.

Meeting \#3 (On Religion): Dewey's work is a seamless web. His thoughts on the value of religious experiences are not disconnected from his views on democracy and education. Democracy and education are both about the maintenance, protection, and enhancement of a growing and fulfilling experiential life. Dewey favoured democracy because it was the most educative form of social life, hence the most conducive to self-realization of connected individuals. Deweyan religious experiences are the manifestation of a rich and varied life lived with full and free communication. This is his ideal about what he felt was worth seeking in experience.

Still, Dewey's attempts to reconstruct words to meet changing situations needs further examination. Words are habits which represent even deeper habits of feeling, belief, and action. These are not easily changed. In a Deweyan sense, we do not as much have habits as we are our habits; our habits are the ways in which we inhabit the world. Changes in habits change our world and are, therefore, unsettling. Dewey knew this but felt that the intelligent reconstruction of habits could build on what was valued and useful in experiences. Since we cannot surgically remove habits and since habits have a tendency to live on and on, we should attempt to intelligently direct their energy to more life-enhancing possibilities. This is a self-correcting process that takes diligence and sensitivity-something that cannot be merely willed, but which can be developed through education. Still, intentionally reconstructing the meaning of basic words can, to say the least, be confusing. There is no guarantee that it will or ought to succeed.

The Bertrand Russell quoted by Michael Rockler in this third session seeks to cut to the bone on key religious issues. No reconstructing terms for him. If he thinks something is intellectually wrong, it is out of there. Certainly, the question could be raised as to whether the intellectual invalidation of a belief rids it once and for all. It would seem that this depends on how deep the belief goes and how unambiguous the object of the belief is. A universal change strategy of either reconstruction or removal seems to ignore context and specifics, in addition to limiting creative questioning. This issue of strategy takes on particular importance when we are involved in the give and take of democratic politics in a pluralistic society. Dichotomous thinking is usually inadequate in handling new developments in complex political issues. Still, there is a need for flexible but principled strategies. 
Also implied in Rockler's version of Russell's incisive belief-removal method is the implication that this is what is necessary to "defy the herd." From a Deweyan perspective, with its emphasis on communication and community through holding things in common, "herd defying" would seem to be an unusual primary concern for someone deeply interested in democracy. Certainly, one should not follow a crowd to do evil; however, one should not be limited to doing good only by oneself. From a Deweyan perspective, it would seem desirable to work to have a crowd stop doing evil and possibly even start doing good. That work can be done from inside or outside the crowd. ${ }^{2}$ This difference in Russellian and Deweyan philosophical styles, methods, and interests will require further exploration. Rockler's surprising claim about the differing intellectual capacities of Russell and Dewey requires no comment.

To summarize these reflections:

1. Dewey and Russell share common ground that becomes apparent when they deal with a foe of liberal democracy or education.

2. Form does affect content. The debate format tended to bring out either/or thinking, a very un-Deweyan way to approach possibilities.

3. Even committed educational liberals can have some questionable interpretations of Deweyan democratic education.

4. Deweyan democracy is integrally connected with other parts of his thinking and needs further articulation.

5. Dewey and Russell approached ideas differently. The former emphasizing reconstruction and the connection to cultural practices; the latter focusing on substantiating knowledge claims and removing unsubstantiated knowledge claims.

6. Points 1-5 have implications for doing Dewey right in terms of democracy and education.

\section{Reconstructions}

Doing Dewey right means being a "pragmatopian." That means not being stuck in a rut but using reflections on past experiences, imagination, and the resources available to attempt to construct a more desirable future. Thus, rather than continuing the debate format, which seems to bring out exaggerated differences and, thus, more heat than light, I would like to use Deweyan explication and Russellian co-operation to deal with a common foe of democracy and education: misunderstanding. Therefore, in order to provide a more cooperative framework, I will attempt to clarify Dewey's approach to democracy and education and, rather than attack Russell, merely ask some questions regarding his way of thinking about some key issues. This, it would seem, would provide a better use of our resources and give us more imaginative possibilities to work with.

Earlier, I mentioned that Dewey and Russell were both humanist philosophers. They were humanists in the sense that neither thought that they could get out of the human perspective; neither thought they could trade upward. Dewey's philosophical project involved working out methods to savour, understand, and better this perspective. In particular, his view of the human perspective focused on four crucial dimensions. Quite simply, he saw humans as evolved, embodied, social problem-solvers (Campbell, 1995). Each of these is essential in understanding his view of democracy. 
First, Dewey took evolution quite seriously. Born in 1859, the year Darwin published Origin of the Species, Dewey thought evolution put a whole new spin on life and its possibilities. As James Campbell (1995) points out, Dewey's biological perspective means "we humans are creatures of aeons of evolution. Our bodies and our minds have evolved, and our institutions and our values have evolved as well"' (p. 29). Events do not come out of nowhere. They involve a long history of adjustment and change, continuity and interaction. Dewey, who understood the importance of the specifics of adjustment and change for all life, begins Democracy and Education (1916) with this biological imperative: Life either uses the energies around itself for renewal or else it dies. As Raymond Boisvert (1993) cogently states, "Drawing on Darwinian biology, Dewey resituates human being within the web of relationships that make up the natural world" (p. 140). Cultural life, the web of relationships that make up our social world, also follows this imperative for renewal. If the young are not brought into a culture's characteristic ways of life, that culture dies out. This renewalthrough-interaction is an important building block for Dewey's democracy.

My question for Russellians is this: To what extent does Russell's philosophy connect with evolution?

Next, Dewey's biological view leads to a naturalistic understanding of mind as an evolved coping device for dealing with a changing world. As biological beings who must adapt to our environments to live, we do not have a separate faculty called mind. Rather, we are our embodied habits for minding the world. If our embodied habits are inadequate for coping with our surroundings, our existence cannot be sustained. If our habits are mindful of the world and help us adapt to more complex situations, we grow. This has implications for democracy as a self-correcting habit for minding our social world.

Taking this even further, Bruce Wilshire (1993) argues that Dewey had a deep sense of what he calls the "body-mind" which radically opposed Cartesian dualism. Mind is a person's whole system of meanings. What we call consciousness comes into being when these meanings do not work. These meanings are built from psycho-physical interactions that go well beyond our conscious functioning. Understanding the implications of Dewey's body-mind has important implications for education and ecology.

My question for Russellians is this: How does Russell's conception of mind connect with nature and society?

In addition, for Dewey, humans are social through and through. This means much more than a mere emphasis on human sociability or even human sociality. Rather, it means that humans as a species evolved by means of connection with others. As individual organisms, it means that without human and cultural contact, we do not become human. Thus, from a Deweyan perspective, we do not start off as "selves" but become so by engaging in joint activities in which the use of our bodies and objects in our environment are consciously co-ordinated to the actions of others. To understate the obvious, the social environment plays a fundamental role in human development. We do not merely live in a social environment, we live by means of a social environment.

A key part of human social development is learning to participate in a community of discourse. Learning to use language involves the development of perspective-taking and the internalization of norms of discourse. Thus, we have a sense of self because we can recognize and be recognized by others. Our self 
is not a metaphysical "Lone Stranger" existing nowhere, but rather involves an internalization of, and the reflection on, our connections to our experienced world (Luntley, 1995). This internalized self is also a specifically-situated self, which is the base we have to work with, for good or ill.

My question for Russellians is this: For Russell, in what sense are humans social?

Finally, humans are problem-solvers. In the process of dealing with our natural and social environment, we face some situations in which our usual habits or customs do not work. In evolved, embodied social beings, this is usually represented by the primal sound, "Gulp!" What should we do when we experience "Gulp"? Ignore it? Keep doing the same thing? Try the first thing that comes to our mind? Freeze? No, Dewey says we have the potential to do better. Humans can use a sustained, disciplined, and creative frame of mind to think through a "Gulp!" and generate and test proposed solutions. In the process of being able to deal with more complex "Gulps!," we develop a wider range of possibilities for more meaningful connections to others and our environment.

More "Gulps!" occur as we have more contacts with others. The development of perspective-taking, open-mindedness, and creative expression enables new possibilities to be constructed. Social problem-solving here means much more than mechanical adjustment of means to established ends for it provides possibilities for reconsidering ends, examining the consequences of differing means, and imagining and constructing new ends. Through participating in this type of social inquiry, individuals have the potential to become more complex and integrated.

Thus, Dewey shows how the intensive aspects of experience can provide the basis for social and individual growth. Without "Gulps!," we would not grow. However, if we do not handle "Gulps!" intelligently, our chances for survival in a pluralistic ever-connecting world are greatly diminished.

My question for Russellians is this: How does Russell suggest we can creatively deal with the tensions of a pluralistic social life?

Just as Dewey and Russell are humanists, so are they philosophers. In addition to having differences on specific issues of logic (Burke, 1994; Tiles, 1988), they also approached philosophy differently. ${ }^{3}$ Dewey is a pragmatist. He comes from a tradition with nineteenth-century roots in such thinkers as Charles Sanders Peirce and William James that is now being carried into the twenty-first century by such diverse philosophers as the anti-philosopher Richard Rorty, the theologian Cornell West, the feminist Charlene Haddock Seigfried, and the secular humanist Paul Kurtz. Certainly diversity and disagreement have a place in this philosophy. Dewey's connection with this diverse group is the commitment to build from the goods found in experience.

Down-to-earth Deweyan pragmatists are not after some teleological architectonic of the good, the true, and the beautiful. Rather, they have learned to construct with their biological rootedness, social-historical situatedness, and the basic ambiguities and uncertainties of experience, lives based on the better, the warranted, and the enlivening. In so doing, building on practice is emphasized.

Practices, according to Peter Manicas (1993),

... are, roughly, ways of doing. Practices include the beliefs of prac-

titioners, the tools they use, their explicit goals, and much else besides. 
Practices are institutionalized (structured) activities, activities which presuppose habits in Dewey's sense, dispositions which carry the legacy of training and custom. (pp. 164-165)

This intellectual concern with practice is not to be reduced to making intelligence practical. Rather, it can be seen as the attempt to make practices intelligible and worthwhile by attending to the values, beliefs, expectations, tensions, and excellences embedded in them. Seeking intelligible and worthwhile practices refers to the development of warranted, grounded principles for our associated living. In a changing world (the only one we have), these practices and principles are never final and are subject to social inquiry as "Gulps!" are encountered. Thus, practices provide a beginning and end point for Deweyan pragmatists in that we find ourselves in a world of social practices on which we can reflect in order to maintain, modify, and enhance our valued ways of living together.

Dewey's pragmatism, with its emphasis on experience and intelligence, is not a traditional compartmentalized professional view of philosophy. It is a reconstruction of philosophy based on the idea that life evolves, runs together, and can be intelligently approached so people can have fulfilling growth experiences. On important issues, we may not have certainty but we can have warrant and we can construct meanings. Pragmatism is, thus, about going from what is to what might be. Kaufman-Osborn (1991) notes that from this perspective "the aim of thinking is not to mirror a finished reality but to anticipate the possibilities disclosed by affairs still very much in the making" (p. vii). This connected and pregnant sense of philosophy which aims to deepen the qualitative dimension of experience is seen in the way Dewey pragmatically connected and reconstructed metaphysics, religion, ethics, epistemology, education, aesthetics, and politics. It can also be seen in the question with which KaufmanOsborn (1991) begins his pragmatic inquiry into the promise of democracy: "What is the quality of our present political experience?" (p. 1).

My question for Russellians is this: How is Russell's view of philosophy connected to other parts of life, particularly his politics?

\section{Deweyan Democracy}

Deweyan democracy is connected to his view of human nature and pragmatic philosophy. It builds on his conceptualization of humans as evolved, embodied, social problem-solvers and his integrative view of philosophy as a practice seeking to understand and better the quality of human experiences and shared life. Dewey's advocacy of democracy is of a particular type of democracy-participatory democracy. As Westbrook (1991) states,

this is the belief that democracy as an ethical ideal calls upon men and women to build communities in which the necessary opportunities and resources are available for every individual to realize fully his or her particular capacities and powers through participation in political, social, and cultural life. (p. xv)

Certainly, this goes well beyond majority rule with respect for minority rights. ${ }^{4}$ It is an educative way of life that connects social inquiry and communication throughout all of culture so that people can become wiser, develop a more fulfilling character, and find more meanings, possibilities, and values in their 
experiences. As a way of life, Stuhr (1993) notes that participatory democracy involves three components: an ideal, cognitive and moral virtues, and a faith.

As an ideal, democracy is not something that already exists but something to be done. This requires an active and imaginative union of the actual and the socially desirable. As Stuhr (1993) points out,

idealizing democracy is the first step in the task of realizing democracy. When, and if, our idealizing imagination does seize upon democracy as a way of life, personal life will express the ideal in action. (p. 47)

Certainly, this has connections with Dewey's stressing the importance of religious experiences which emotionally connect us with worthwhile projects.

Deweyan participatory democracy also involves cognitive and moral virtues. As Wood (1992) notes,

this includes the ability to think in terms of private interests and public goods; the commitment to learn from, but not be blinded by, the past; the ability to intelligently enter public debate; the commitment to social justice; and a willingness to try new things. Developing the disposition and skills to practice these civic virtues is an important part of, but not limited to, the aims and practices of schools in and for a democracy. (p. 81)

Finally, Deweyan democracy involves a democratic faith. The goal of having people become "hopeful meliorists [who] ... would act together to secure the goods of experience" (Westbrook, 1991, p. 362) is built on a faith in the power of intelligence to imagine a future which is the projection of the desirable in the present, and to invent the instrumentalities of its realization (Dewey, 1980, p. 48). At the very least, this involves the belief that human nature is not fundamentally evil, that social life can be positive, and that human intelligence can be sophisticated (Kelly, 1995). This does not negate the fact that people may be apathetic, not knowledgeable enough, or not virtuous enough to participate in democratic practices-only that people have the moral and cognitive capacity to do this. For Dewey, the cure for the inadequacies of democracy is more democracy. This is a pragmatist's faith in the possibilities of experience. As Dewey states, "Since the process of experience is capable of being educative, faith in democracy is all one with faith in experience and education" (1991, p. 229). Once more, the connection of the educative, religious, and democratic is made.

However, even with an active ideal, deeply-practiced cognitive and moral virtues, and a strong civic faith, doing Deweyan democracy is not easy. We live in a complex, pluralistic world filled with social injustice; economic inequalities; international, local, and domestic violence; cumulative environmental crises; economic systems pushing for ever more consumption above all else; regimes with anti-democratic traditions; wheeling and dealing power elites; and information control and manipulation by global corporations and the mass media. All of this can be overwhelming just to cope with, let alone democratically transform. Dewey provided philosophic grounding which pointed to democratic possibilities that could be mined from evolved, embodied, social intelligence. He did not offer precise answers or concrete programs. This is where the going gets tougher. There are not usually simple solutions or guarantees of success when approaching complex issues in democratic ways. In fact, even the feasibility and desirability of doing Deweyan democracy can be 
questioned in general or in specific instances. 5 A pragmatic strength of Dewey's approach is that this questioning can be done in democratic ways for democratic purposes, thus adding to the culture of democratic practice. Doing Dewey right means to be an active participant, creator, and critic of this culture of democratic practice. Many voices, be they Deweyan or not, are needed for the development of such a democratic culture, be it Deweyan or better.

My final question: Can Russellians and Deweyans work together for the development of a democratic culture?

\section{Perching}

One of the strengths (and weaknesses) of working from a Deweyan perspective is the felt difficulty of trying to make a final statement. There is never a final word that will settle matters for all time, for doing Dewey right is to think in terms of "? and ;" not ". and !". Still, life involves flights and perchings and it is time to rest and survey the horizon.

This conference is centered on the theme "Identity, Citizenship, and Democracy."6 I have offered a Deweyan perspective that builds on the way our identity is evolved and embodied in our relations with others; citizenship is seen as character-developing participation in open, public discourse; and democracy is viewed as an enabling ideal and a way of life aimed at the reconstruction of culture.

\section{Notes}

${ }^{1}$ These papers were published by the John Dewey Society (Novak, 1993).

${ }^{2}$ Outside the crowd, however, is not a view from nowhere. It is rather a view from another perspective. The Deweyan perspective is, when possible, to seek to change the crowd into a public or publics. In The Public and Its Problems (1927), Dewey develops this perspective.

${ }^{3}$ However, in spite of some major difference between Russell and Dewey, Hager (1996) categorizes both of them as rational and non-foundational in their approach to knowledge.

${ }^{4}$ Dewey distinguishes between democracy as a system of government and democracy as a social ideal. Certainly, they are not exclusive. Dewey's major concern, however, is that democracy as a social ideal provides the opportunities for both individual and social growth. As Rosenthal (1993) states, the "moral import of democracy is the ideal of community life itself. Rationally-directed change leads to growth both for the individual and the community, and authentic growth of self as well as of the institutions and practices of the community is inherently moral"' (p. 71).

${ }^{5}$ John Patrick Diggins (1994) provides a recent criticism of the pragmatic underpinnings of a general approach to life. A rich source of historical and recent criticisms are found in J.E. Tiles (1992). Specific criticisms would have to depend on specific contexts. Nothing in Deweyan democracy says you have to be foolishly romantic, although perhaps the case could be made that it certainly helps to be a seasoned meliorist.

${ }^{6} \mathrm{~A}$ reference to the 1996 CSSE conference, Brock University. 


\section{References}

Boisvert, Raymond, D. (1993). Heteronomous Freedom. In John J. Stuhr (Ed.), Philosophy and the Reconstruction of Culture: Pragmatic Essays after Dewey (pp. 131-149). Albany: State University of New York Press.

Burke, Tom (1994). Dewey's New Logic: A Reply to Russell. Chicago: University of Chicago Press.

Campbell, James (1995). Understanding John Dewey: Nature and Cooperative Intelligence. Chicago: Open Court. millan Co.

Dewey, John (1916). Democracy and Education. New York: The Mac-

Dewey, John (1927). The Public and its Problems. New York: Henry Holt \& Co.

Dewey, John (1934). Art as Experience. New York: Minton, Balch \& Co. Books.

Dewey, John (1938). Experience and Education. New York: Collier

Dewey, John (1980). The Need for a Recovery of Philosophy. In Jo Ann Boydston (Ed.), John Dewey: The Middle Works, 1899-1924, Volume 10: 1916-1917 (pp. 3-48). Carbondale: Southern Illinois University Press. (Original work published 1917.)

Dewey, John (1991). Creative Democracy-The Task Before Us. In Jo Ann Boydston (Ed.), John Dewey: The Later Works, 1925-1953, Volume 14: 1939-1941 (pp. 224-230). Carbondale: Southern Illinois University Press. (Original work published in 1939.)

Diggins, John Patrick (1994). The Promise of Pragmatism: Modernism and the Crisis of Knowledge and Authority. Chicago: University of Chicago Press.

Hager, Paul (1996). A Russellian Approach to Philosophy of Education. In Alvin Neiman (Ed.), Philosophy of Education 1995. Champaign-Urbana: Philosophy of Education Society.

Kaufman-Osborn, Timothy, V. (1991). Politics/Sense/Experience: A Pragmatic Inquiry into the Promise of Democracy. Ithaca: Cornell University Press.

Kelly, A.V. (1995). Education and Democracy: Principles and Practices. London: Paul Chapman.

Luntley, Michael (1995). Reason, Truth, and Self: The Postmodern Reconditioned. London: Routledge.

Manicas, Peter T. (1993). Naturalizing Epistemology: Reconstructing Philosophy. In John J. Stuhr (Ed.), Philosophy and the Reconstruction of Culture: Pragmatic Essays after Dewey (pp. 151-174). Albany: State University of New York Press.

Mayer, Samuel (Ed.) (1985). Dewey and Russell: An Exchange. New York: Philosophical Library.

Novak, John M. (Ed.) (1993). Lingering Educational Disputes: The Russell-Dewey Debate. In Current Issues in Education, 10(1), 24-39.

Novak, John M. (1994). The Talk and the Walk of Democratic Teacher 
Education. In John M. Novak (Ed.), Democratic Teacher Education: Programs, Processes, Problems, and Prospects (pp. 1-6). Albany: State University of New York Press.

Robertson, Emily (1992). Is Dewey's Educational Vision Still Viable? In Gerald Grant (Ed.), Review of Research in Education, 18 (pp. 335-381). Washington: American Educational Education Research Association.

Rockler, Michael J. (1995). Russell vs. Dewey on Religion. Free Inquiry, 15(4), 36-39.

Rosenthal, Sandra B. (1993). The Individual, the Community, and the Reconstruction of Values. In John J. Stuhr (Ed.), Philosophy and the Reconstruction of Culture: Pragmatic Essays after Dewey (pp. 59-77). Albany: State University of New York Press.

Russell, Bertrand (1945). A History of Western Philosophy. New York: Simon and Schuster. and Wang.

Ryan, Alan (1988). Bertrand Russell: A Political Life. New York: Hill

Ryan, Alan (1995). John Dewey and the High Tide of American Liberalism. New York: Norton.

Sleeper, R.W. (1991). Introduction. In Jo Ann Boydston (Ed.), John Dewey: The Later Works, 1925-1953, Volume 14: 1939-1941 (pp. ix-xxiv). Carbondale: Southern Illinois University Press.

Stuhr, John J. (1993). Democracy as a Way of Life. In John J. Stuhr (Ed.), Philosophy and the Reconstruction of Culture: Pragmatic Essays after Dewey (pp. 37-57). Albany: State University of New York Press.

Tiles, J.E. (1988). Dewey. London: Routledge.

Tiles, J.E. (Ed.). (1992). John Dewey: Critical Assessments (Volume II: Political Theory and Social Practice). London: Routledge.

Westbrook, Robert B. (1991). John Dewey and American Democracy. Ithaca: Cornell University Press.

Wilshire, Bruce (1993). Body-Mind and Subconsciousness: Tragedy in Dewey's Life and Work. In John J. Stuhr (Ed.), Philosophy and the Reconstruction of Culture: Pragmatic Essays after Dewey (pp. 257-272). Albany: State University of New York Press.

Wood, George H. (1992). Schools That Work: America's Most Innovative Public Education Programs. New York: Dutton. 